\title{
FORMS OF THE EXPRESSION OF COMMUNICATIVE DISCOURSE IN ENGLISH FICTION TEXTS
}

Summary. The article investigates the terminological polysemy of discourse on different levels of linguistics as well as in different fields of knowledge. Discourse is analyzed as a unit of statements, as intersubjective communication or dialogue within the historical period of time including personal experience of the native speakers, their individual knowledge, attitudes, intentions and emotions. Three forms of discourse are found: discourse being intersubjective dialogue; discourse of human consciousness; discourse of the prior or the existing cultural tradition. The author identified. three forms of discourse: discourse as an intersubjective dialogue; discourse of human consciousness; discourse as an accumulator of a previous or existing cultural tradition. In certain areas of communication, the knowledge of standard forms of language replicas may correspond to the intention of the communicator, but as soon as the subject of communication is complicated, their use is inadequate.

Keywords: polysemy, discourse, textlinguistics, discourse analysis, native speaker, communication.

Радзіевська О.В.

Донбаський державний педагогічний університет

\section{ФОРМИ ВИРАЖЕННЯ КОМУНІКАТИВНОГО ДИСКУРСУ В АНГЛІЙСЬКОМУ ХУДОЖНЬОМУ ТЕКСТІ}

Анотація. В статті досліджується полісемія термінологічної одиниці «дискурс» на різних рівнях самої лінгвістики, так і в різних областях гуманітарного знання. Аналізуеться дискурс як черговий вислів, тобто інтерсуб'ективна комунікація або діалог всередині історичного часу, які включають особистісний досвід носіїв мови, накопичують їх попередні індивідуальні знання, установки, наміри та емоції. Виділено три форми дискурсу: дискурс як інтерсуб'ективний діалог; дискурс свідомості людини; дискурс як акумулятор попередньої або існуючої культурної традиції. Автором визначені три фрорми дискурсу: дискурс як інтерсуб’ективний діалог; дискурс свідомості людини; дискурс як акумулятор попередньої або існуючої культурної традищії. У певних сферах спілкування знання стандартних форм мовних реплік може відповідати інтенція комунікантів, але як тільки предмет спілкування ускладнюеться, їх вживання виявляеться неадекватним. Специфіка комунікації як діяльності проявляеться в тому, що процес формування думки е процес творчий. Думка народжуеться на основі задуму і відповідно до нього формуеться. Це означає, що навчання, спрямоване на заучування готових форм, перешкоджає процесу «створення» і вираження думки. Для вираження своїх думок необхідно володіння механізмами породження власного висловлювання на основі мовного досвіду і усвідомленого розуміння функціонування мовних засобів у процесі комунікації. Ця вимога доводить доцільність звернення при аналізі навчальних текстів до основним категоріям комунікативної лінгвістики. Комунікативно-діяльнісний підхід, на який спираемося ми в своєму дослідженні, ступив вперед від наведеного вище, в тому сенсі, що в основі підручника лежить єдина, природно розвивається комунікативна ситуація, де одні і ті ж люди (персонажі, а слідом за ними учні) у міру знайомства один з одним і швидко наростаючого запасу мовних засобів, поглиблюються по ходу курсу в обговорення все більш серйозних життевих проблем, слідуючи моделі комунікативної діяльності, закладеної в підручнику, в його тексті як одиниці навчання.

Ключові слова: полісемія, дискурс, лінгвістика тексту, аналіз дискурсу, носій мови, комунікація.

The problem of the research. The grow-

1 ing interest in the study of discourse and its widespread use in various contexts is a hallmark of the linguistic problem situation of the late XX early XXI century.

According to N.D. Arutyunova, author of the article on discourse in the Linguistic Encyclopedic Dictionary, «discourse has become an interdisciplinary field of knowledge, in which, along with linguists, philosophers, sociologists, psychologists, artificial intelligence specialists, ethnographers, semiotic literary scholars, stylists and historians participate» [1, p. 137].

Today, the scope of the term "discourse" is so great that it has become possible to talk about the polysemy of this terminological unit at different levels of linguistics itself, and in various fields of humanitarian knowledge.

The concept of "discourse" owes its appearance in linguistics to Harris, the author of the distribu- tion method, who in the 1950s used the concepts of "discourse" and "discourse analysis" for distributive analysis of not only individual sentences, but also texts, considering them in the context of the sociocultural situation of the statement [6, p. 87].

A little later in the French linguistic tradition, the term "discourse" denoted language and speech in general (translated from French discourse "speech, speech»).

The aim of the article is to disclose the role of discourse in English fiction texts.

Later they began to associate "discourse" with "linguistics of the text", referring to the study of the laws governing the formation and functioning of texts.

Rapidly entering domestic linguistics along with translation works, this term begins to drift between the concepts of text, context, functional style, sublanguage, speech, dialogue, etc.

The analysis of research works. The problem of distinguishing and correlating the concepts 
of discourse and text, discourse and speech, discourse and language, discourse and communication is reflected in domestic and foreign linguistics in the works of M.K. Bisimalieva, E.A. Ivanova, About G. Revzina, F.S. Bacevich, O.V. Alexandrova, D. Kristal, D. Maldidier, M. Pesce. However, the problem of defining discourse is still relevant, primarily due to the lack of consensus on what should be understood by this term.

In the "Short Dictionary of Text Linguistics Terms», T. Nikolaeva defines discourse as "a text linguistics term used by a number of authors in meanings that are almost homonymous. The most important of them: 1) coherent text; 2) the oral-colloquial form of the text; 3) dialogue; 4) a group of statements, interconnected by meaning; 5) a speech work as a given (written or oral)» $[1$, p. 36].

Let us turn to the third paragraph of the above list of definitions of discourse - dialogue, which, in our opinion, is not only one of the forms of existence of discourse, but also one of its defining characteristics. In our opinion, the identification and emphasis of such essential characteristics of a discourse will lead to a clearer understanding of it and, possibly, will help solve the problem of determining this terminological unit.

Based on the analysis of the works of E. Benvenista, P. Serio, M. Foucault, B.M. Gasparov, O.G. Revzin, it comes to the conclusion that the unit of discourse is statements that function as material entities [2, p. 27]. This echoes the opinion of M. Pesceau, according to which discursiveness is nothing but a "space of utterances» [3, p. 27].

We have to talk about discourse as a series of statements, i.e., as intersubjective communication or dialogue. Here, dialogue is understood in its direct meaning, that is, as "a form of speech, which is a series of successively interconnected speech acts and involving at least two participants, each of which alternately becomes either the addressee or the addressee of speech" [4, p. 37].

The very knowledge of another person (which becomes inalienable with intersubjective communication), according to M.M. Bakhtin, is always dialogical, because here the activity of the knower is combined with the activity of the knowable:

«The subject (personality) cannot be perceived and studied as an object, because as an object it cannot be silent. Therefore, his knowledge can only be dialogical» [3, p. 45].

Jürgen Habermas studies intersubjective dialogue. The discourse of the German philosopher has the ability to discuss with the free public - criticize the premises of social being, reflect, reconstruct. He calls this kind of discourse "practical» [2, p. 38].

The sincere desire of its participants for truth and mutual understanding; mutual recognition of the equivalence and maturity of its subjects, the absence of other interests besides the interest (desire) to achieve a balanced consensus are the main features of discursive communication, according to V.M. Chuguenko [6, p. eleven].

Based on the positions of cognitive linguistics, E.S. Kubryakova and O.V. Alexandrova mean by discourse the cognitive process associated with the actual production of speech. It is necessary to create a speech product, since the text is the end result of the process of speech activity, resulting in a certain complete (and fixed) form. Hence the conclusion that a text can be interpreted as a discourse only when it is really perceived and falls into the current consciousness of the person who perceives it [2, p. 26].

Therefore, in this context, we can talk about discourse as a dialogue of a speech work or text with the human consciousness perceiving them. It is also interesting to cite the arguments of P. Serio, who believes that discourse assumes and creates a kind of "ideal addressee» that differs from the "speech perceiver" [3, p. 88]. The "ideal recipient," that is, the reader, is the main object of influence and therefore indirectly always present. The alleged dialogue that will take place during the direct reading of the article is evidenced by rhetorical questions, which, in turn, introduces laid-back, revitalizing intonations typical of journalistic texts.

Studying the discourse from the standpoint of cognitivism, L.V. Kutsenko claims that "one of the most important results of more than twenty years of development of cognitology is the idea of an inextricable relationship between the processes occurring in human memory and the processes that determine the construction and understanding of language messages" [4, p. 11]. This statement also applies to discourse.

Even M. Foucault wrote that in the life of discourse an inevitable demand arises of a kind of "return" to the source. Foucault set his goal to identify the "historical unconscious" of different eras. Based on the concept of the linguistic nature of thinking, he reduces the activities of people to their "speech", that is, discursive practices [6, p. 406]. But modern philosophy (for example, M.K. Mamardashvili), developing the idea of M. Foucault, tries to define the nature of memory in scientific discourses as a movement from "oblivion" to "return" of thought (for example, the concept of "intertextuality" in literature) [5, p. 67].

This is the basis to speak of dialogue within historical time as a complex hierarchy of knowledge, including the personal experience of native speakers, accumulating their previous individual knowledge, attitudes and intentions, feelings and emotions. In journalism, this can be either a dialogue with history or a dialogue with an existing cultural tradition. The latter can manifest itself in terms of content (relevant, topical topics) and in terms of expression (through reflection in the language of cultural trends of a given historical period).

In accordance with general trends in the development of the language, one can observe the inclusion of conversational elements in the discourse, as well as the borrowing of fashionable words that characterize a given historical period.

Conclusion. So, we have identified three forms of discourse: discourse as an intersubjective dialogue; discourse of human consciousness; discourse as an accumulator of a previous or existing cultural tradition. And these aspects, in our opinion, must be taken into account in any analysis of such a complex and controversial process as the transfer of information. Indeed, information is the most general category, including not only linguistic, but also extralinguistic factors that contribute to a holistic and harmonious worldview.

Linguistics of the text, which is closely connected with the theory of communication, psycholinguistics, psychology, sociopsychology and other sci- 
ences, allows you to rethink many issues related to the analysis and modeling of educational texts. The need to address textual problems is due to the fact that when studying the content side of units of one level, it is necessary to refer to units of a higher lev- el up to a text. The text should be considered as the unit of instruction, and the statement as its organic part, its lower limit, the minimum operational unit of interaction of speaking subjects in the context of educational interaction.

\section{References:}

1. Arutyunova, N.D. (1990). Lingvisticheskij enciklopedicheskij slovar [The linguistic encyclopedic dictionary]. Moscow: Sov.enc., 235 p. (in Russian)

2. Gutorov, V.A. (2001). Lingvofilosofskaya priroda nauchnogo filologicheskogo diskursa [Linguistic and philosophical nature of scientific philological discourse]. Visnik Harkivskogo universitetu, no. 10, p. 69.

3. Ivanova, E.A. (2001). Kommunikativnyj status teksta v diskurse - hudozhestvennom, virtualnom, sakralnom. Filologichni aspekti doslidzhennya diskursa [The communicative status of the text in discourse - fiction, scientific, virtual sacral. Philological aspects of the discourse research]. Visnik Harkivskogo universitetu, no. 33, $167 \mathrm{p}$.

4. Ilin, I.P. (2001). Diskurs $i$ diskursivnye praktiki. Postmodernizm [Discourse and discourse practice]. Moscow, 230 p. (in Russian)

5. Krysin, L.P. (1998). Tolkovyj slovar inoyazychnyh slov [The dictionary of foreign words]. Moscow: Russkiy yazyk, 140 p. (in Russian)

6. Kucenko, L.V. (2001). Obgruntuvannya kognitivnoyi modeli rozuminnya zhurnalistskogo tekstu [The analyzing of cognitive model of understanding of journalistic text]. Dnipropetrovskij universitet. Visnik. Ser. Literaturoznavstvo. Zhurnalistika, no. 4, pp. 95-99.

\section{Список літератури:}

1. Арутюнова Н.Д. Дискурс. Лингвистический энциклопедический словарь. Москва, 1990. 235 с.

2. Гуторов В.А. Лінгвофілософська природа наукового та філософського дискурсів. Філологічні аспекти дослідження дискурсу. Вісник Харківського університету. Сер. Філологія. 2001. Вип. 10. С. 69.

3. Иванова Е.А. Коммуникативный статус текста в дискурсе - художественном, виртуальном, сакральном. Філологічні аспекти дослідження дискурса. Вісник Харківського університету. Сер. Філологія. 2001. Вип. 33. С. 167.

4. Ильин И.П. Дискурс и дискурсивные практики. Постмодернизм. Словарь терминов. Москва, 2001. 230 с.

5. Крысин Л.П. Толковый словарь иноязычных слов. Москва : Рус. яз., 1998. 340 с.

6. Куценко Л.В. Обгрунтування когнітивної моделі розуміння журналістського тексту. Дніпропетровський університет. Вісник. Сер. Літературознавство. Журналістика. 2001. № 4. С. 95-99. 